„Bohemistyka” 2019, nr 2, ISSN 1642-9893

Andrzej CHARCIAREK

DOI: $10.14746 /$ bo.2019.2.5

Uniwersytet Śląski w Katowicach

\title{
Využití paralelního korpusu v translatologii (na základě česko-polského InterCorpu)
}

Keywords: InterCorp parallel corpus, translation theory, translation equivalence, phrasemes, Czech, Polish

Klíčová slova: paralelní korpus InterCorp, translatologie, překladová ekvivalence, frazémy, čeština, polština

\section{Abstract}

This article is devoted to the use of the Intercorp parallel corpus in translation theory.

In the research selected phrasemes have been used in order to show possibilities of using the parallel corpus in translation. Particular focus has been put on translation equivalence and its criteria with reference to the material from the parallel corpus.

Also, the specificity of Czech-Polish and Polish-Czech translation has been described, which provided a context for particular InterCorp resources.

The analysis indicated usefulness of the corpus-driven material in the search of adequate translator's solutions. The article contributes to theoretical analysis related to the role of parallel corpora in the translator's work.

Tento článek je věnován využití paralelního korpusu InterCorp v teorii překladu.

Ve výzkumu byly použity vybrané fráze, které ukazují možnosti využití paralelního korpusu InterCorp. Zvláštní pozornost byla věnována rovnocennosti překladů a jeho kritériem s ohledem na materiál z paralelního korpusu. Také byla popsána specificita česko-polského a polsko-českého překladu, který poskytoval kontext pro konkrétní zdroje InterCorp.

Analýza ukázala užitečnost materiálu korpusu při hledání vhodných překladatelských řešení. Článek přispívá $\mathrm{k}$ teoretickému badání, které ukazuje úlohu paralelních korpusů v práci překladatele.

Od vzniku paralelních korpusů zásadním problémem byl jejich malý rozsah nesrovnatelný s velkými jednojazyčnými korpusy. Dalším problémem byla také malá žánrová rozmanitost textů $\mathrm{v}$ korpusech 
tohoto druhu, protože většina paralelních korpusů obsahuje převážně beletristické texty.

V tomto ohledu česko-polský Intercorp vybočuje z řady mnoha paralelních korpusů. Podle velikosti je polština šestým největším cizojazyčným korpusem InterCorpu a každý polský text má v korpusu svou českou verzi.

Rozsah polského InterCorpu v poslední verzi 10 činí již přes 85 milionů slov a obsahuje:

- beletristické texty (přes 23 milionů slov),

- právní texty Evropské unie z korpusu Acquis Communautaire (téměř 20 milionů slov),

- zápisy jednání Evropského parlamentu z let 2007-2011 z korpusu Europarl (téměř 13 milionů slov),

- publicistické články a zpravodajství z webových stránek VoxEurop (téměř 2,5 milionů slov),

- filmové titulky z databáze OpenSubtitles (téměř 27 milionů slov).

Na rozdíl od předchozích 10. verze zahrnuje novou kolekci: překlady Bible - Nového i Starého zákona (přes 0,5 miliónu slov). Z uvedených čísel je patrné, že v česko-polském InterCorpu největší podíl tak mají filmové titulky z OpenSubtitles, tj. platformy neprofesionálních překladů.

To vše znamená, že korpus InterCorp poskytuje velmi cenný soubor žánrově odlišných textů pro česko-polský překlad. Podstatné je, že Intercorp obsahuje rozmanité texty dnešní doby, což je velmi důležité pro zkoumání současné češtiny i polštiny a zásadním způsobem ovlivňuje kvalitu překladu.

Z hlediska překladatele je důležité, že Intercorp uvádí směr překladu, tj. je známý zdrojový jazyk, z něhož se překládalo. Zdá se, že tento technický parametr je základní pro zajištění kvalitního překladu. Kromě toho InterCorp umožňuje provedení zpětného překladu, který dodatečně ověřuje překladatelská řešení. Tímto způsobem je možné odhalit případné chyby, včetně interferenčních.
Je dobře známo, že korpusy (včetně paralelních) trpěly a trpí nedostatkem mluvených textů. Získávání zápisů mluvených projevů je totiž nákladné a časově náročné. Je třeba si uvědomit také, že se některé mluvené texty z objektivních důvodů překládat nebudou.

Je jasné, že v určité míře se mluvená řeč projevuje v beletristických textech (jadro InterCorpu), ve skutečnosti se nejedná o autentické texty ale jenom o stylizaci - jednotlivé dialogy postav v próze. Analýza souborů Intercorpu verze 10 však ukazuje, že tento korpus v určité míře zachycuje autentický mluvený jazyk. Týká se to především texto̊ z korpusu Europarl, které registrují mluvený jazyk ve formálních komunikačních situacích. Zčásti to lze říci i o filmových titulcích, které jsou zápisy mluvených projevů v běžných situacích. Je jasné, že tyto zdroje nejsou ideální, zejména amatérské filmové titulky mají řadu nevýhod. Jejich největší slabinou je, že většinou jde o překlad do češtiny nebo polštiny z jiných jazyků (převážně z angličtiny). Výsledkem toho je v podstatě porovnání dvou překladů ${ }^{1}$.

Je samozřejmé, že pro překladatele jsou nejlepším materiálem př́imé překlady mezi oběma jazyky v obou směrech bez třetího jazyka jako prostředníka. Nicméně př́imé překlady z češtiny do polštiny a z polštiny do češtiny najdeme v beletrii a v textech jednotlivých kolekcí: Acquis Communautaire, Europarl a VoxEurop.

Přesto však pro překlad polsko-český poskytuje InterCorp unikátní možnosti vyhledávání překladových ekvivalentů na základě tertium comparationis ${ }^{2}$. Pod tímto pojmem rozumíme situaci v původním textu, kterou překladatel konceptualizuje a nachází analogickou v cílovém textu. Volba jednotlivých jazykových prostředků záleží na dané situaci a její interpretaci překladatelem. V této souvislosti paralelní korpus umožňuje analýzu stejné komunikační situace, ve které jsou známy všechny její součástí. Je zřejmé, že se taková situace týká jen

\footnotetext{
${ }^{1}$ Navíc amatérské filmové titulky většinou nejsou zpracovány na základě dialogových listin. Profesionální titulky lze považovat za intralingvální překlad scénáře.

${ }^{2}$ Podrobně o tertium comparationis pojednává Tadeusz Piotrowski v článku »Tertium comparationis« w przektadoznawstwie (Piotrowski 2011).
} 
přímého překladu. Problém je ale v tom, že naprostá většina překladů v InterCorpu je překladem anglicko-českým a anglicko-polským. $\mathrm{V}$ porovnání př̀ekladů se potýkáme s dvojnásobnou konceptualizací stejné situace českým a polským překladatelem. V praxi to znamená, že oba překladatelé hledají optimální překlad s ohledem na situaci a př́ijemce textu (Čecha nebo Poláka). Takže nemáme typický vztah mezi originálem a překladem, ve kterém originál je původní, a překlad je sekundární. Pokud budeme chápat ekvivalenci jako vlastnost překladu, která se opírá o podobnost s originálem, tak ten neexistuje máme dva překlady. Je samozrejmé, že překlady napodobují stejný originál, ale nejsme schopni určit nakolik každý z nich je ekvivalentní originálu. Př́klady se dájí přece rozlišovat podle stupně ekvivalence. $\mathrm{Z}$ toho důvodu můžeme $\mathrm{v}$ tomto kontextu hovořit o více nebo méně ekvivalentních překladech. Ekvivalence je jev relativní a může být hodnocena podle různých kritérií.

Všechny tyto faktory způsobují, že dva cizojazyčné (český a polský) překlady stejného originálu mohou být do značné míry odlišné.

S ohledem na všechny tyto skutečnosti uživatel korpusu nezískává hotový seznam párů ekvivalentů, ale získává mimořádně cenný jazykový materiál k dalšímu zpracování a použití v překladu. InterCorp v praxi poskytuje překladateli unikátní př́ležitost navádění na spravný překlad a dobře ilustruje základní problém ekvivalence, který se týká jednotek různých rovin jazykového systému: výrazů, slovních spojení, vět nebo textu.

Kvalita korpusového materiálu je různá a záleží na jeho zpracování. V InterCorpu originály a překlady beletristických textů jsou ručně zarovnané po větách (zarovnání mezi texty v polštině přes českou verzi), zatímco ostatní kolekce jsou zarovnány automaticky. Tato skutečnost se pochopitelně odráží v kvalitě jednotlivých součástí korpusu. Vzhledem k automatickému zarovnání texty kolekcí obsahují zjevné chyby, a proto výsledky zkoumání mohou být zavádějící. V takové situaci je relevantní podrobně zkontrolovat každý výskyt. To je největší slabina a problém kolekcí, zejména pro nezkušeného uživatele.
U výše zmíněných amatérských filmových titulků je počet chyb a nepřesností mnohem vyšší než v ostatních textech. Neměli bychom zapomínat, že v př́ípadě filmových titulků existují různá časová a prostorová omezení. V překladatelské praxi to znamená nejčastějí vynechání nebo kompresi textu ${ }^{3}$. Tato poslední operace může vést $\mathrm{k}$ výrazným změnám gramatických struktur a lexikálních prvků. Ve skutečnosti to znamená, že $\mathrm{v}$ překladu při zachování smyslu dochází $\mathrm{k}$ formálním změnám, které znemožňují považovat originál a jeho překlad za ekvivalenty. Ve srovnání s profesionálními je především problematická kvalita amatérských titulků, a to z několika důvodů. Zaprvé existuje různá úroveň jazykových a stylistických dovedností prekladatelů. Tato poznámka se týká znalostí jak zdrojového jazyka, tak mateřštiny (češtiny nebo polštiny). Zadruhé amatérští překladatelé zpravidla nemají k dispozici dialogovou listinu (s přepisem dialogů) nebo scénář (s přepisem dialogů a popisem akce) a překládají (titulkují) z odposlechu. Zatřetí se neprovádí korektura a úprava amatérských titulků někým jiným než samotnými překladateli.

$\mathrm{S}$ ohledem na tyto faktory se proto $\mathrm{v}$ amatérských titulcích $\mathrm{z}$ databáze OpenSubtitles vyskytuje více nesprávných překladů než v profesionálních, což vůbec neznamená, že amatérské titulky jsou automaticky nekvalitní. Z toho jen vyplývá, že uživatelé korpusu by měli jen věnovat větší pozornost získáným výskytům a důkladně je ověřovat.

Předností použítí paralelního korpusu je určité omezení případných stylistických, lexikálních a sémantických chyb. Uživatel polsko-českého InterCorpu porovnává originál (nebo překlad, jak již bylo řečeno) s překladem na základě určitého počtu výskytio. Texty v InterCorpu jsou opatřeny spolehlivými metainformacemi, což znamená, že každý jednotlivý výskyt může být zkontrolován. Lze určit např́klad původní jazyk originálu, rok jeho vzniku, jeho autora, jeho překla-

\footnotetext{
${ }^{3}$ Je nutné poznamenat, že na rozdíl od profesionálních překladatelů, pro amatérské titulkáře je hlavní normou překladu titulků věrnost zdrojovému textu, co je někdy v rozporu $\mathrm{s}$ jeho redukci. Tato poslední operace může vést $\mathrm{k}$ vypouštění určitých informací. Zdá se, že z tohoto důvodu amatérské překlady obsahují někdy až čtyřřádkové titulky.
} 
datele apod. To vše umožňuje vyhledávání překladových ekvivalentů v relevantních kolekcích, protože se určité druhy frazémů vyskytují $\mathrm{v}$ textech různých žánrů a žánrových forem. Je zcela jasné, že prakticky každý frazém patřri do konkrétní roviny stylistické, a tedy se vztahuje k funkčním stylovým oblastem: odborné, hovorové, publicistické, řečnické, administrativní apod. Omezení vyhledávání překladových ekvivalentů na některé kolekce do značné míry vylučuje stylisticky nevhodné ekvivalenty a významně přispívá ke zlepšení adekvátnosti překladu.

Výše uvedené skutečnosti mají význam u polsko-českého překladu, který má svá specifika. Současnou polštinu lze rozdělit do dvou základních variant: spisovného jazyka (język literacki) a mluveného jazyka (język potoczny). Na rozdíl od polštiny situace současné češtiny je složitější. Lze celkem s jistotou tvrdit, že v obou jazycích existují spisovné psané varianty a je mezi nimi symetrie. Problém ale spočívá v tom, že v češtině se za sociálních a historických okolností vytvořily dvě formy mluveného jazyka, tj. nespisovná - obecná čeština a spisovná - hovorová čeština. Tento poslední termín někteří lingvisté neuznávají z toho důvodů, že hranice mezi hovorovou a obecnou češtinou není ostrá (Štícha a kol. 2013, s. 26).

Z toho vyplývá, že se obecná čeština staví do opozice vưči spisovné a hovorové. Jak píše Marie Čechová, „nejběžnějším útvarem sloužícím běžnému dorozumívání je obecná čeština. Obecná čeština je na západní části našeho území útvarem tvořícím základ b ě žn é m $1 \mathrm{u}$ v y, na východě území pak jsou jím náře čí či in te rdia lekty moravské a slezské, ale i tam ovlivňuje obecná čeština běžnou mluvu (alespoň ve velkých městech, jako je Brno), tj. mluvu městskou, a její vliv se promítá na území západní části Moravy i mimo města (po řeku Moravu)" (Čechová a kol. 2008, s. 59).

Podobný jev v současné polštině neexistuje a proto je v podstatě nepřeložitelný ${ }^{4}$.Tato skutečnost by měla být vzata $\mathrm{v}$ úvahu v procesu

${ }^{4}$ Grażyna Balowska (2006, s. 25-46) užívá pojmu czeski język potoczny nieliteracki, a Elżbieta Szczepańska (2003, s. 289-298) ho nepřekládá do polštiny. česko-polského a polsko-českého překladu, zejména mluvených textů. Takže žanr překládaného textu vyžaduje od uživatele korpusu využití relevantní kolekce. Pokud to bude běžná komunikace, uživatel korpusu by měl zvolit filmové titulky a beletristické texty s dialogy. V př́ípadě textů právní nebo administrativní povahy nejlepším zdrojem budou kolekce Acquis Communautaire a Europarl. Pro překlad publicistických textů je nejvhodnější využít kolekce VoxEurop. Proto je nezbytně nutné se dobře seznámit s obsahem jednotlivých kolekcí. Při vyhledávání je důležité vědět, co přesně bylo do nich zařazeno. V opačném případě provedená na irelevantních datech analýza nepřinese objektivní a reprezentativní informace o jazyku, což lze ukázat na konkrétních příkladech.

Je zcela jisté, že polsko-český InterCorp může posloužit jeho uživatelům k překladu jednotlivých slov. Již několik let je k tomu určena aplikace Treq na základě dat korpusu InterCorp. Přesto však by měl InterCorp především sloužit $\mathrm{k}$ překladu víceslovných jednotek, a tedy frazémů, idiomů a ustálených kolokací. Právě víceslovné jednotky jsou nejdůležitější v procesu překladu. Není tedy žádným překvapením, že v současné lingvistice se staly frazémy středem pozornosti překladatelů a lexikografư ${ }^{5}$. Takový postoj je trreba považovat za odůvodněný podle předpokladu, že víceslovných lexikálních jednotek je v každém jazyce více než jednoslovných. Intercorp jako zdroj množství různých textů vytváří optimální podmínky pro podrobné sledování kontextů, ve kterých se víceslovné jednotky vyskytují. Tato skutečnost úzce souvisí se zkoumáním různých kontextových posunů významu jazykových jednotek na základě korpusových dat, která umožňují odhalit nové či existující, ale dosud neregistrované významy.

Na rozdíl od klasických papírových překladových slovníků obsahuje InterCorp to, co je v překladu nejdůležitější - textové ekvivalenty, které tvoří základní jednotky v procesu translace. Jeho relativně velký rozsah zajišt'uje zkoumání jazyka příznačného pro celonárodní

${ }^{5}$ Nejlepším př́íladem v tomto ohledu je Polsko-ruský slovník překladových párů (Polsko-rosyjski stownik par przekładowych). 
komunitu - jazyka, který tato komunita skutečně používá v psaných a mluvených projevech.

Jak InterCorp může být užitečný pro překladatele demonstrujeme na konkrétních př́kladech. Známý a kvalitní Velký česko-polský frazeologicky slovník (Wielki czesko-polski słownik frazeologicky, dále jen VCPFS), nezpracovaný na základě korpusových dat, uvádí frazém být/bejt kapitola sama pro sebe a jeho polské ekvivalenty:

\section{být / bejt kapitola sama pro sebe}

pot. 'wyraźnie się różnić; być innym, nie takim samym'

to inna para kaloszy / to osobny rozdział / być z innej bajki

S. nemít obdoby/obdobu / být bez obdoby (VČPFS 2009, s. 184)

Jak je uvedeno výše, tento slovník uvádí jako synonyma být/bejt kapitola sama pro sebe frazémy nemít obdoby/obdobu / být bez obdoby a jeho polské ekvivalenty to inna para kaloszy / to osobny rozdziat / być z innej bajki. Kromě toho hodnotí frazém být/bejt kapitola sama pro sebe jako hovorový.

Slovník spisovného jazyka českého (dále jen SSJČ) tu stylovou charakteristiku nepotvrzuje ${ }^{6}$. Navíc není to frazém, který patří do obecné češtiny, což VČPFS poněkud naznačuje (bejt). A proto bychom měli spíše mluvit o frazému být kapitola sama pro sebe. Právě v takové podobě ho budeme dále používat. Kromě toho SSJČ definuje zkoumaný frazém jako 'o tom by bylo třeba mluvit zvlášt' (zejména pro označení něčeho špatného $\left.{ }^{7}\right)^{, 8}$. Důležité také je, že tento slovník uvádí kromě být kapitola sama pro sebe (jako typický frazeologismus za kosočtvercem) i frazém to je jiná kapitola s významem 'něco jiného"9. Ten poslední není registrován v VČPFS.

${ }^{6} \mathrm{Http} / / /$ ssjc.ujc.cas.cz/search.php?hledej=Hledat\&heslo=kapitola\&sti=EMPTY \&where=hesla\&hsubstr=no [dostup: 18.11.2018]

${ }^{7}$ Analýza materiálu v českých korpusech tuto skutečnost nepotvrzuje.

$8 \mathrm{Http} / / /$ ssjc.ujc.cas.cz/search.php?hledej=Hledat\&heslo=kapitola\&sti=EMPTY $\&$ where=hesla\&hsubstr=no [dostup: 18.11.2018].

9 Http://ssjc.ujc.cas.cz/search.php?hledej=Hledat\&heslo=kapitola\&sti=EMPTY \&where=hesla\&hsubstr=no [dostup: 18.11.2018].
VČPFS v definici být kapitola sama pro sebe chybí informace 'zejména pro označení něčeho špatného', což je správné řešení. Frazém být kapitola sama pro sebe se používá jak pro označení něčeho špatného, tak pro označení něčeho dobrého.

Česko-polský InterCorp registruje jenom 8 výskytů frazému být kapitola sama pro sebe (7 výskytů v krásné literatuře, 1 výskyt v Europarl) a registruje jenom 2 ekvivalentní páry:

být kapitola sama pro sebe - to osobny rozdział (1 výskyt),

být kapitola sama pro sebe - to rozdział sam w sobie (1 výskyt).

Jak je vidět, korpusový materiál není dostatečný pro naši analýzu. Navíc ilustruje problém neadekvatního překladu. Dostatečně srozumitelná pro Poláky fráze to rozdział sam w sobie se v polštině prakticky nepoužívá (ani jeden výskyt v Národním korpusu polského jazyka - Narodowy Korpus Języka Polskiego - dále jen NKJP) ${ }^{10}$. InterCorp neregistruje žádný pár česko-polských ekvivalentů s frazémy to inna para kaloszy a być z innej bajki uvedenými ve slovníku.

Pro překladatele je důležitou otázkou, že se frazém být kapitola sama pro sebe v samotném českém InterCorpu vyskytuje v korpusu relativně zř́ídka (17 výskytů: $16 \mathrm{v}$ beletrii, $1 \mathrm{v}$ Europarl) (srov. tabulka 1. Výskyt frazému být kapitola sama pro sebe v českém InterCor$\mathrm{pu})$.

Pokud jsou možnosti prozkoumání tohoto frazému v InterCorpu omezené, můžeme využít i neparalelního korpusu. V SYN 2015 se tento frazém vyskytuje častěji - 29 krát (14 výskytů v publicistice, 10 výskytů v oborové literatuře, 5 výskytů v beletrii). Zdroje jednoznačně potvrzují jeho spisovnost a zároveň fungování v určitých typech textů.

Za pozornost stojí 6 výskytů spojení to je kapitola sama pro sebe v českém InterCorpu a 7 výskytů v SYN 2015 (srov. tabulka 2. Výskyt frazému být kapitola sama pro sebe v českém InterCorpu - 1 a tabulka 3. Výskyt frazému být kapitola sama pro sebe v českém InterCorpu).

\footnotetext{
${ }^{10} \mathrm{Http}: / / w w w . n k j p . u n i . l o d z . p 1$ [dostup: 18.11.2018].
} 
Jak je vidět, uvedené korpusy ČNK často registrují frazém to je kapitola sama pro sebe, který plní $\mathrm{v}$ textu funkci osobitého shrnutí.

$\mathrm{V}$ tomto prípadě ekvivalentem českého frazému s významem 'něco úplně jiného' je spiše polský protějšek to osobny rozdziat, který tento slovník výstižně popisuje jako jeho ekvivalent ${ }^{11}$. Tento frazém zdařile zachovává význam to je kapitola sama pro sebe, stejnou stylovou rovinu a míru expresivity. Navíc komponent kapitola je př́tomen v polském ekvivalentu, což má svůj význam ohledně adekvátnosti překladu. Ekvivalent to osobny rozdziat, podobně jako to je kapitola sama pro sebe, funguje především v publicistických a beletristických textech.

Problém, který bychom měli vzít $\mathrm{v}$ úvahu, spočívá $\mathrm{v}$ tom, že $\mathrm{v}$ polštině se tohoto frazému používá $\mathrm{v}$ doslovném a přeneseném významu. $\mathrm{V}$ takové situaci je třeba důkladně zkontrolovat každý výskyt, což dobře ilustruje tabulka 4. (Použití frazému osobny rozdziat v polšitně $\mathrm{v}$ doslovném a přeneseném významu).

Jak je vidět, jen ve dvou př́ipadech je tento frazém použit v přeneseném významu, v ostatních výskytech (12 výskytů) se používá v doslovném (neidiomatickém) významu. Takže v př́padě polského frazému osobny rozdziat se dá mluvit o určitém typu homonymie.

Další významnou otázkou je podoba, $v$ jaké podobě tento pár translačních ekvivalenti̊ by měl být registrován v překladovém slovníku.

VČPFS nabízí tvar být/bejt kapitola sama pro sebe, což nelze považovat za chybu. Nicméně korpusový materiál jednoznačně prokazuje, že se v češtině často používá výše uvedený frazém to je kapitola sama pro sebe.

Vzhledem k tomu, že v databázi polského InterCorpu je zaznamenáno málo výskytů frazému to osobny rozdziat, jsme nuceni ho hledat $\mathrm{v}$ textech NKJP ${ }^{12}$, který registruje 27 výskytů tohoto frazému, v drtivé většině v přeneseném významu. Tato skutečnost opravňuje považovat

${ }^{11}$ Elektronický Velký slovník polského jazyka a Jiný slovnik polského jazyka tento frazém neregistruje.

${ }^{12} \mathrm{Http} / / /$ www.nkjp.uni.lodz.pl [dostup: 18.11.2018]. frazémy to je kapitola sama pro sebe a to (jest) osobny rozdziat za translační pár.

Tato situace dokládá, jak při sestavování párů translačních ekvivalentů je důležité přesné vymezení významů a stylistické charakteristiky zkoumaných frazémů.

Lze konstatovat, že analýza provedena na základě korpusových textů do jisté míry zpochybňuje další dva frazémy to inna para kaloszy a być z innej bajki jako ekvivalenty být kapitola sama pro sebe.

Frazémy to inna para kaloszy a być z innej bajki mají poměrně silný př́znak expresivity a v souvislosti s tím rys hovorového stylu. Tato ekvivalence není také opodstatněná $\mathrm{z}$ důvodu větší obraznosti obou polských frazémů, což i potvrzuje polsko-český InterCorp. Korpus registruje 15 výskytů frazému to inna para kaloszy: 9 výskytů v krásné literatuře (v dialozích), 7 výskytů v titulcích (srov. tabulka 5. Výskyt frazému to inna para kaloszy v polštině).

Překlad v opačném směru (výchozím bodem je frazém to inna para kaloszy) potvrzuje tyto závěry. Dvojice ekvivalentů to inna para kaloszy - být kapitola sama pro sebe se nevyskytuje ani jednou. Mimochodem polsko-český InterCorp uvádí možné varianty polského frazému: to zupetnie inna para kaloszy (8 výskytů), to już inna para kaloszy (2 výskyty), to już zupetnie inna para kaloszy (1 výskyt), to całkiem inna para kaloszy (1 výskyt), to catkowicie inna para kaloszy (1 výskyt). Malý počet výskytů nestačí, aby prokazal, že se tak skutečně ř́ká, ale 8 výskytů frazémů to zupetnie inna para kaloszy o něčem svědčí. A proto překladatel by měl vědět, že se taková varianta nebo varianty používají v řeči.

Je vidět, že všechny výskyty pocházejí z beletrie ( 8 výskytů) a filmových titulků ( 7 výskytů), většina $z$ nich (12 výskytů) je překladem $\mathrm{z}$ angličtiny do češtiny a polštiny. Přímý překlad polsko-český a polsko-český opět zcela chybí, a proto angličtina jako zdrojový jazyk ovlivňuje oba translaty. Možná proto (včetně překladatelských nepřesností) se v češtině vyskytují ekvivalenty s jistou redukcí významu (nedostatkem obraznosti): to je (úplně) néco jiného (4 výskyty), to je (úplně) jiná věc (3 výskyty). 
Dvojice ekvivalentů to inna para kaloszy - být kapitola sama pro sebe se nevyskytuje ani jednou.

Jako třetí možný polský ekvivalent frazému být kapitola sama pro sebe VČPFS uvádí być z innej bajki. V Česko-polském InterCorpu se žádný pár být kapitola sama pro sebe - być z innej bajki nevyskytuje. Není to překvapení, protože oba frazémy spadají do různých stylistických rovin. Na rozdíl od být kapitola sama pro sebe, polský frazém być z innej bajki z hlediska stylistické př́śslušnosti je hovorový.

Zkoumání frazému być z innej bajki (8 výskytů) v InterCorpu objevuje jeho, jak se ukazuje, frekventovanou variantu to już inna bajka (s variantami to już inna bajka, to zupetnie inna bajka, to już całkiem inna bajka apod. - 10 výskytů v titulcích), která se v VČPFS neuvádí.

Nelze pochybovat o tom, že frazémy to inna para kaloszy a to inna bajka jsou synonymní jednotky. Svědčí o tom jak kontexty jejich použití, tak texty, ve kterých se vyskytují. A proto z důvodů stylistické odlišnosti oba frazémy jsou méně vhodné překladové ekvivalenty být kapitola sama pro sebe.

Vyhledávání v paralelním korpusu prakticky velmi často přináší nečekané výsledky a objevuje nové možné ekvivalenty. Takto se objevuje dosud nezmíněný a vhodný vzhledem k obraznosti frazém to je jiné kafe (1 výskyt), který mimochodem VČPFS zahrnuje jako hovorový ve formě to je jiný kafe a ve významu 'coś zupełnie innego, różnego'. VČPFS uvádí heslovou stat' jiný tabák/kafe/žrádlo, ve které ukazuje polský ekvivalent (zupetnie) inna para kaloszy (WČPFS 2009, s. 561). Mimochodem z těch tř́ frazémů jen jiný kafe se běžně používá v současné češtině ${ }^{13}$. Je však zrrejmé, že jeden výskyt není dostatečný důvod k tomu, aby se dal určitý frazém považovat za překladový ekvivalent. Nicméně tento výskyt navádí na možný překladový ekvivalent, který je nutno podrobně zkontrolovat.

InterCorp ve směru čeština - polština zachycuje 17 výskytı̊ to je jiný kafe (14 výskytů v titulcích, 3 výskyty v krásné literatuře - v dia-

${ }^{13} \mathrm{~V}$ česko-polském InterCorpu frazémy jiný tabák a jiný žrádlo nejsou prakticky registrované: jiný tabák - žádný výskyt, jiný žrádlo - 1 výskyt. lozích), ale bohužel jednoznačně nenaznačuje ekvivalentní česko-polský pár (srov. tabulka 6. Výskyt frazému to je jiný kafe v českém InterCorpu).

Uvedená na konci článku tabulka 6. dobře ilustruje to, jak důležitá je otázka správné analýzy korpusového materiálu. Je třeba mít na vědomí, že zkoumaný frazém může mít různou podobu (hovorová varianta tohle, nářeční tohlenc) a zahrnovat fakultativní prvky (ale, $u z ̌)$. Pro srovnání: původní frazém v ustálené podobě to je jiný kafe vyskytuje se v InterCorpu jen 7 krát.

Jak je vidět, někdy je problematická významová správnost překladu. Převážným zdrojem chyb je nesprávné převedení významu na úrovni jak jediné lexikální jednotky, tak celé věty. Dá se předpokládat, že je to často způsobeno interferencí z výchozího (většinou anglického) textu nebo automatickým zarovnáním. Někde lze vysledovat jistou nezkušenost a neobratnost překladatele (zejména $v$ amatérských titulcích), který do hovorových nebo dokonce nespisovných výpovědí vybírá prostředek ve skutečnosti z jiné vrstvy jazyka. Ve filmových titulcích z databáze OpenSubtitles z různých důvodů často nacházíme celou řadu překladatelských řešení, která zní přirozeně, ale zároveň je více doslovná, méně idiomatická, např.: to je jiný kafe - to inna rzecz, to je jiný kafe - to coś innego, to zupetnie inna para kaloszy - to je néco jiného, to zupetnie inna para kaloszy - to je jiná věc. Na druhou stranu je to jev poněkud typický pro překlad (obsahují neutrálnější lexikum i syntax). Právě v tom spočívá přednost korpusů, které obsahují množství textů a díky tomu nabízejí řadu možností adekvátního překladu jednotlivých frazémů $\mathrm{v}$ různých kontextech s ohledem na základní sociodemografické charakteristiky, jako je pohlaví, věk a úroveň vzdělání mluvčích. Je ale třeba mít na zřeteli, že v korpusech máme k dispozici množství překladů, které zastupují konkretní idiolekty jejich autorů, tj. jejich jazykové návyky, odlišný osobní styl, oblíbené a nadužívané výrazy a slovní spojení, ale třeba i jazykové chyby.

V případě pochybností ohledně fungování frazému to je jiný kafe (počet výskytů není přece velký) překladatel může využít samotný 
český soubor InterCorpu, který zachycuje jeho 61 výskytů: 32 - v krásné literatuře - především dialogy, 29 - v titulcích. 54 krát se vyskytuje tvar to je jiný kafe, výrazně méně jenom 7 výskytů má varianta to je jiné kafe, jehož použítí v překladu běžné neformalní komunikace je třeba považovat za stylistickou chybu.

Překladatel má možnost dodatečně ověřovat výskyty, které byly získány InterCorpem, pomocí Korpusu SYN 2015. Tento korpus registruje to je jiné kafe 17 krát (srov. tabulka 7. Výskyt frazému to je jiné kafe v Korpusu SYN 2015).

Frekvenční seznam doplněný o informace o výskytu dobře ilustruje fungování tohoto frazému v určitých textech (srov. tabulka 8 . Frekvenční seznam výskytu frazému to je jiné kafe).

Jak je vidět, frazém to je jiné kafe se nepoužívá v běžné komunikaci, vyskytuje se především v psané publicistice, kromě toho i v oborové a krásné literatuře. Tato informace je pro překladatele důležitá ze stylistického hlediska, protože pomáhá zabránit př́ípadným stylistickým nepřesnostem.

Výše uvedený výzkum umožňuje sestavení překladových párů s ohledem na sféru jejich použití (spisovná čeština, hovorová čeština):

to je kapitola sama pro sebe - to osobny rozdział,

to je jiné kafe - to osobny rozdział, to inna para kaloszy, to inna bajka,

to je jiný kafe - to inna para kaloszy, to inna bajka.

Pokud jde o pořadí jednotlivých ekvivalentů, rozhoduje o tom výše zmíněný stupeň ekvivalence. Na prvním místě se nachází nejvhodnější varianta př̀ekladu.

Provedená analýza pomocí InterCorpu potrvrzuje jeho užitečnost v překladatelské praxi:

- pomáhá odhalit větší možnosti překladu pomoci získávání nepředpokládaných a nečekaných frazémů jako překladových ekvivalentů;

- rozšíruje počet gramatických a lexikálních transformací;

- ilustruje použití určitých frazémů v jednotlivých žánrech;

- empiricky ověřuje a doplňuje informace uvedené v slovnících.

\section{Zkrátky}

NKJP

SSJČ

VČPFS

Narodowy Korpus Języka Polskiego. Online: http://www.nkjp.pl [dostęp: 18.11.2018]

Slovník spisovného jazyka českého. Online: http://ssjc.ujc.cas.cz [dostup: 18.11.2018].

T. Z. Orłoś (eds.), Wielki czesko-polski słownik frazeologiczny. Kraków: Wydawnictwo Uniwersytetu Jagiellońskiego, 2009.

Literatura

B a lowska G., 2006, Problematyka czeszczyzny potocznej nieliterackiej (tzw. obecná čeština) na tamach czasopisma »Naše řeč» w latach dziewięćdziesiatych, „Bohemistyka”, $\mathrm{nr}$ 1, s. 25-46.

B a ń k o M. (eds.), 2000, Inny stownik języka polskiego, t. 1-2, Warszawa.

B a ń c z y k Ł., D y b a l s k a R., V a vřín M., 2017, Korpus InterCorp-polština, verze 10 z 1.12.2017. Praha: Ústav Českého národního korpusu FF UK Online: http://www.korpus.cz [dostup: 18.11.2018].

Če chová M., Krčmová M., Minářová E., 2008, Současná stylistika. Praha: Nakladatelství Lidové noviny.

L e w i c k i R., 2017 Zagadnienia lingwistyki przekladu. Lublin: Wydawnictwo Uniwersytetu Marii Curie-Skłodowskiej.

P i o tr o w s k i T., 2011, »Tertium comparationis« w przekladoznawstwie, [w:] Metodologie językoznawstwa. Od genu języka do dyskursu, red. Piotr Stalmaszczyk, Łódź: Wydawnictwo Uniwersytetu Łódzkiego, s. 175-191.

R o s e n A., V a v řín M., Z a s in a A. J., 2017, Korpus InterCorp-čeština, verze 10 z 1. 12. 2017. Praha: Ústav Českého národního korpusu FF UK. Online: http://www.korpus.cz [dostup: 18.11.2018].

Š tí c h a F. a kol., 2013, Akademická gramatika spisovné češtiny. Praha: Academia.

S z c ze p a ń s k a E., 2003, Obecná čeština w literaturze czeskiej, „Bohemistyka”, nr 4, s. 289-298. 


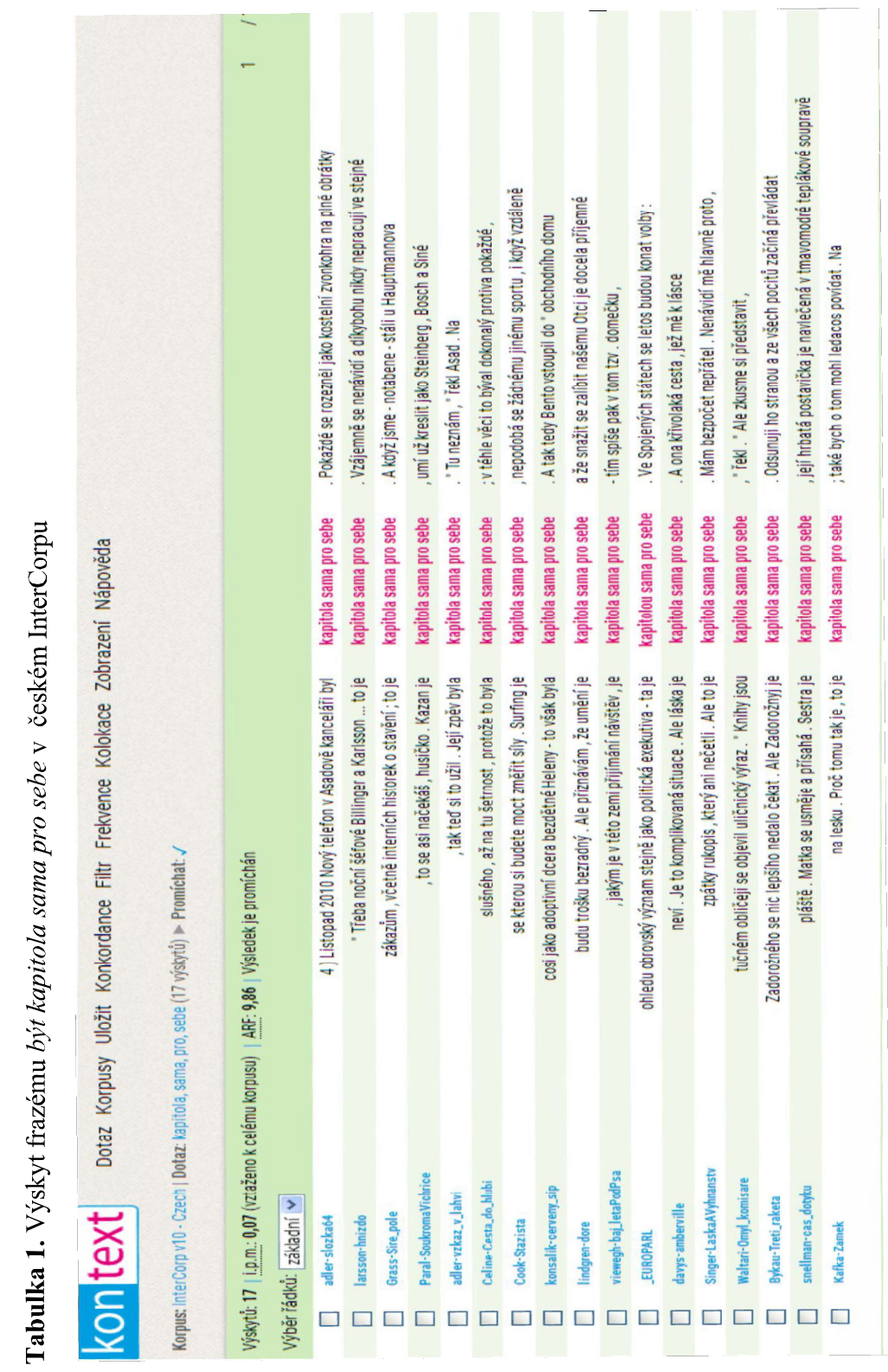

209

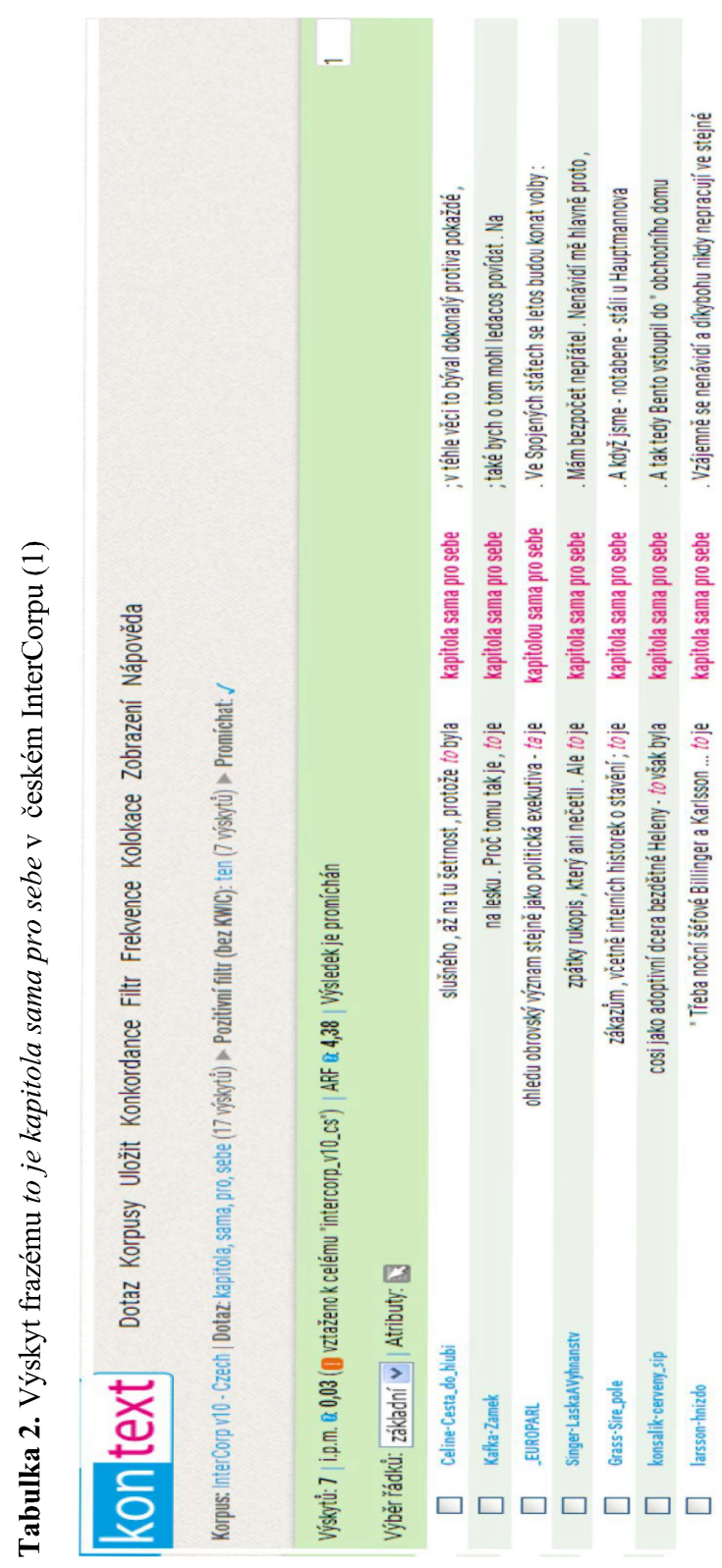

210 

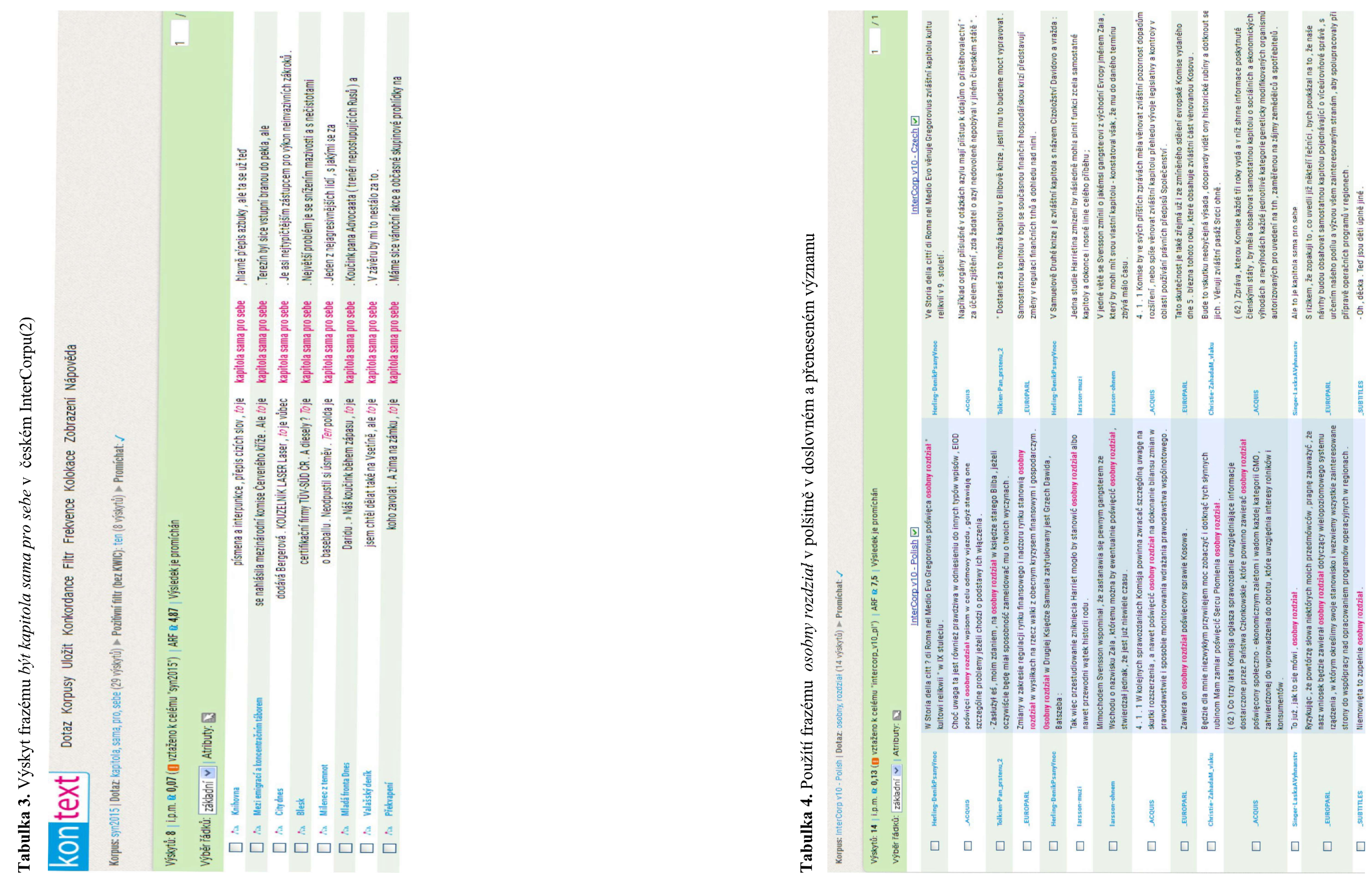


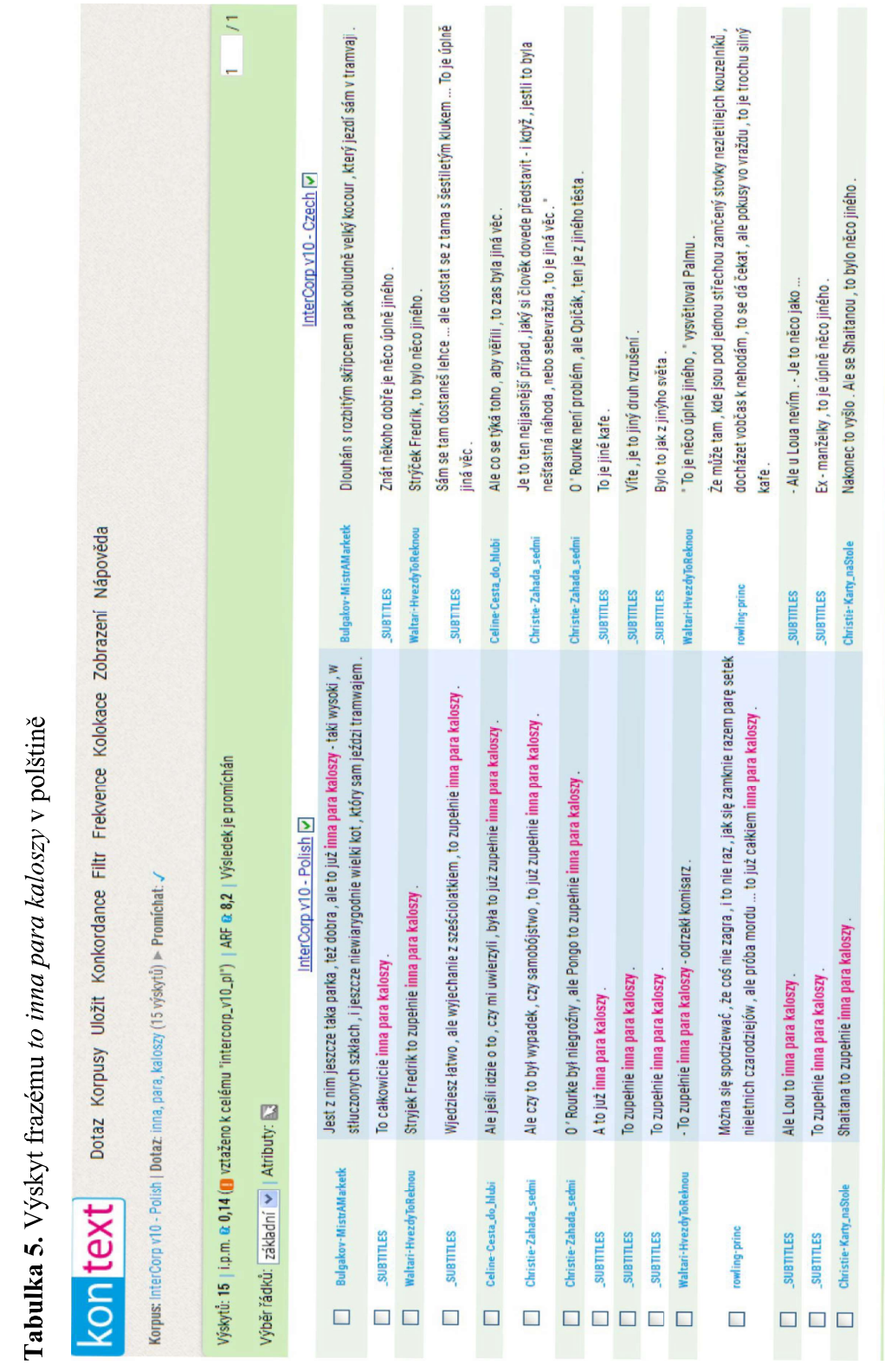

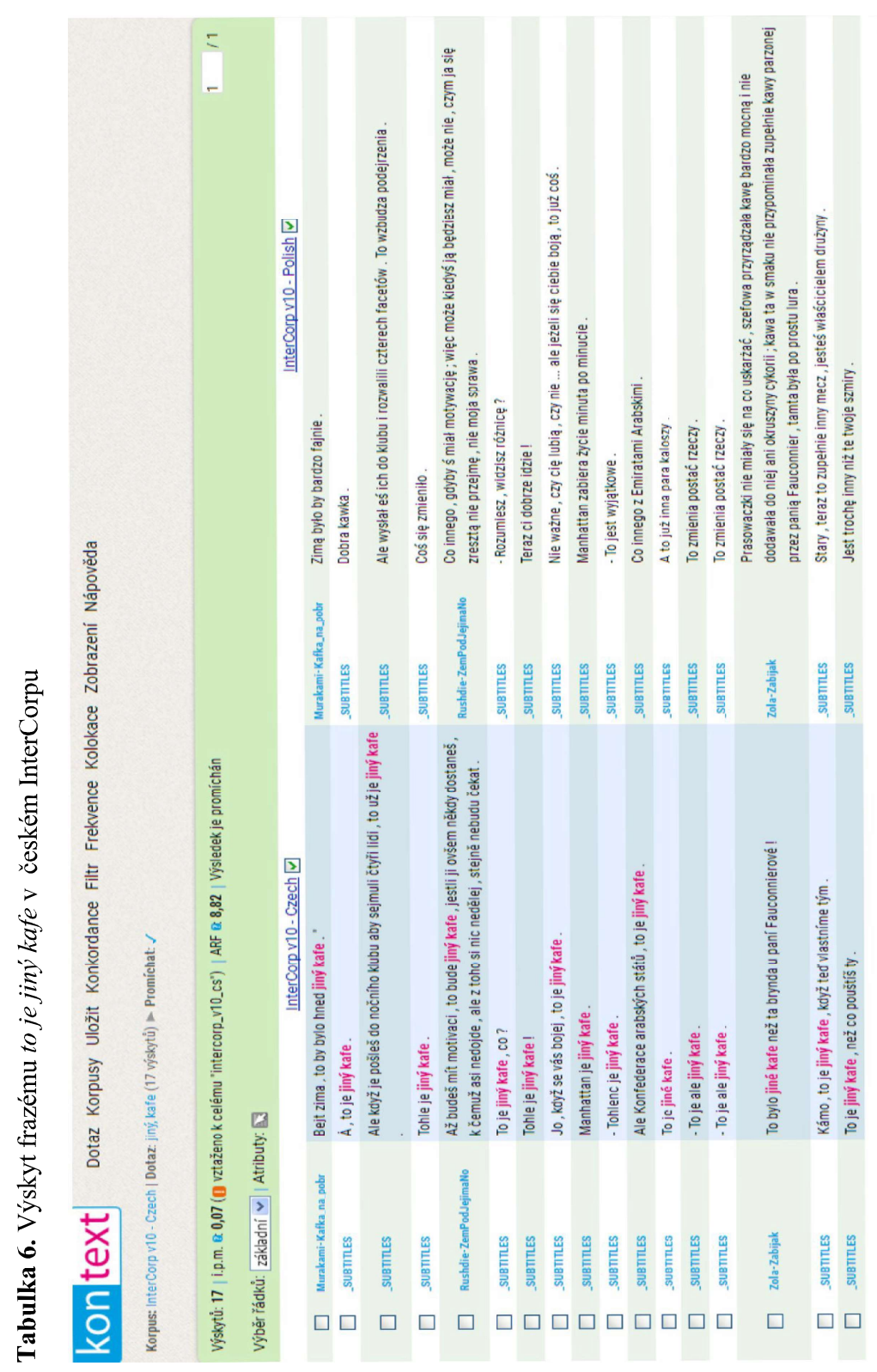

214 


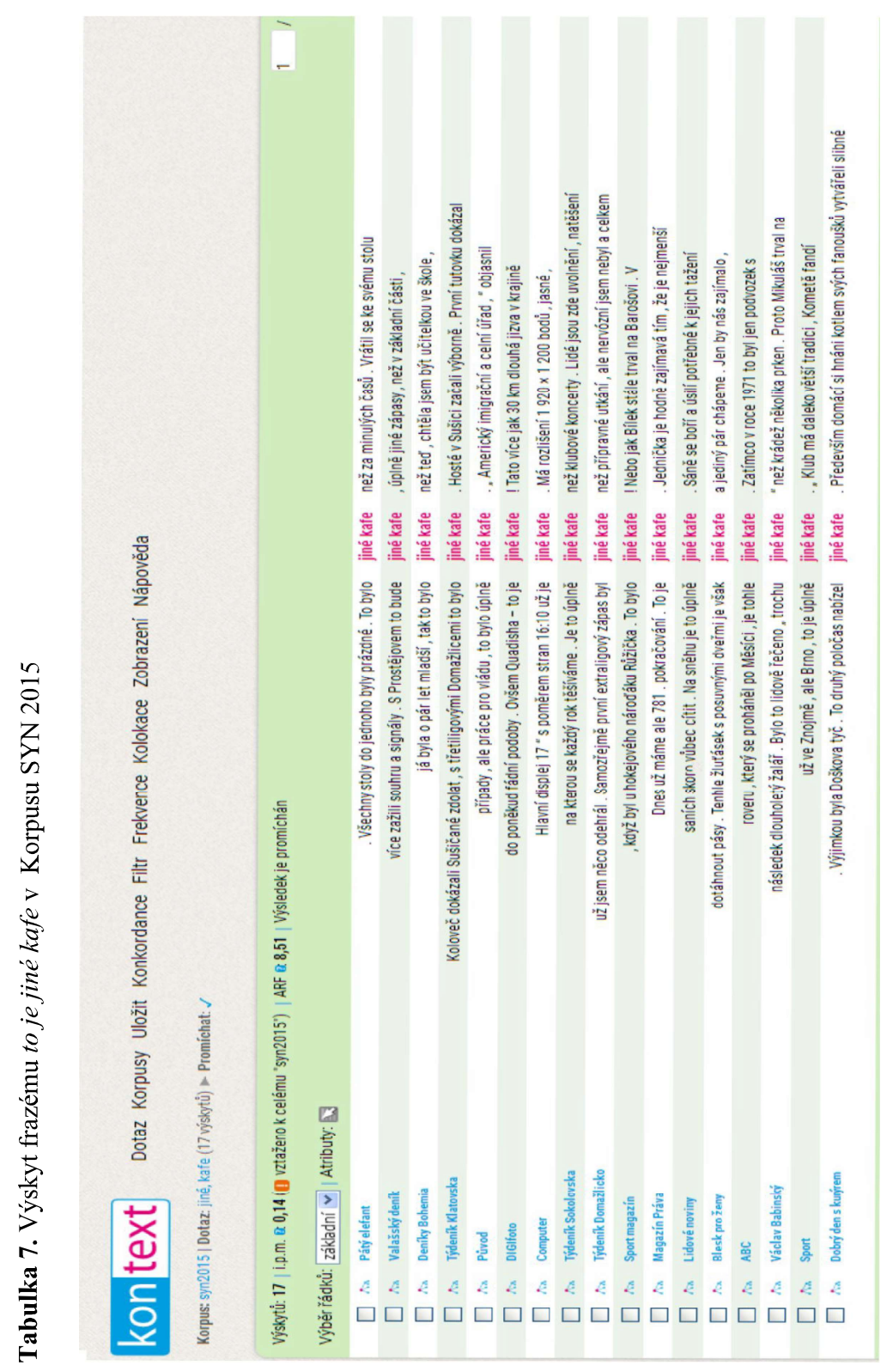

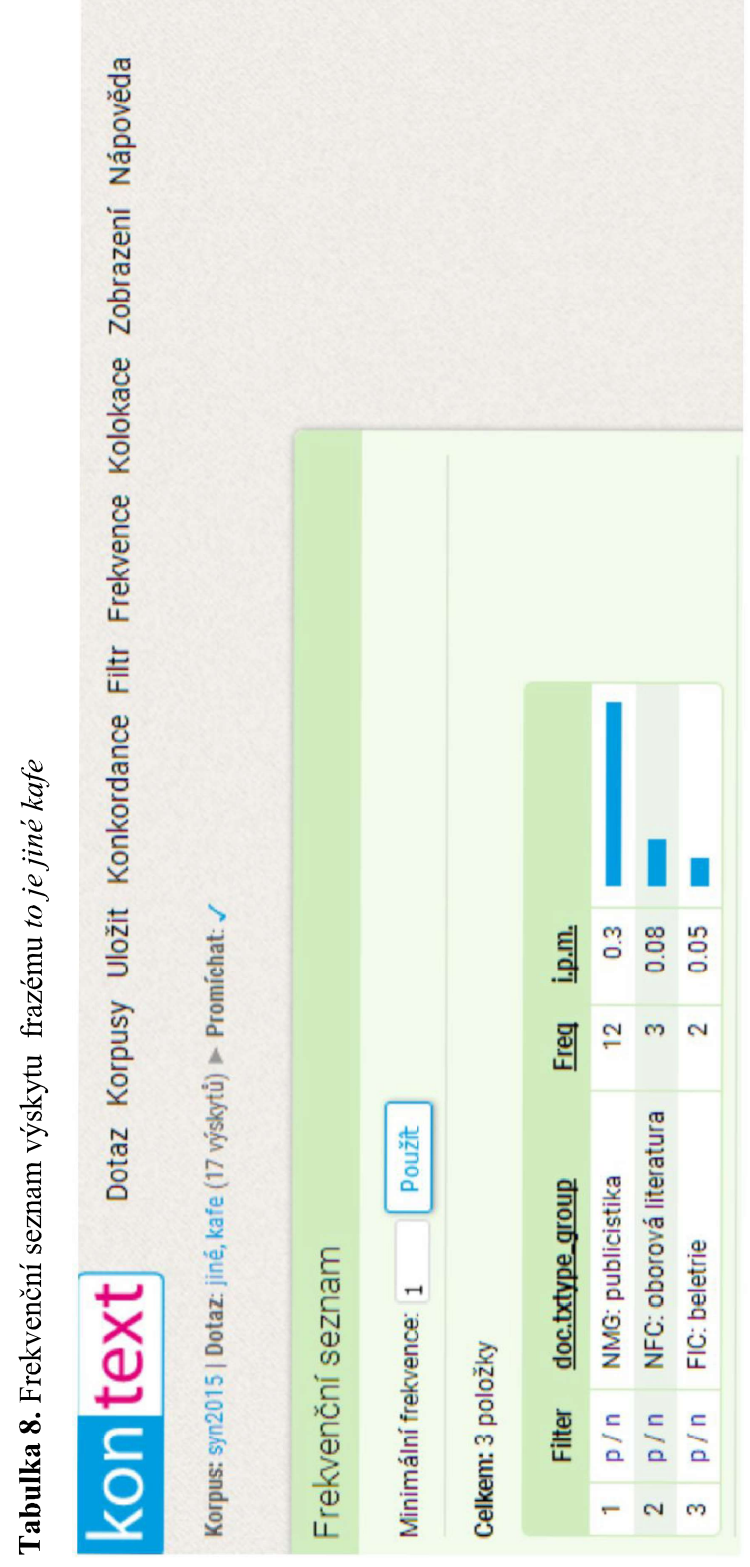

216 